\title{
Los lugares del trauma. Reflexiones en torno a sus procesos de memoria
}

\author{
Júlia Faria | Dpto. de Arquitectura, Universidad de Alcalá
}

URL de la contribución <www.iaph.es/revistaph/index.php/revistaph/article/view/5022>

¿Qué imágenes mentales aparecen de inmediato cuando se emplea la palabra patrimonio? ¿Surgirá, entre las infinitas posibilidades, en la mente de cualquier individuo perteneciente a una sociedad Ilamada postindustrial, una primera acepción de patrimonio como lugar traumático? ¿Qué es el trauma y su relación con los procesos de memoria?

Desde luego, éste es un tema complejo que necesita de una visión inherentemente multidisciplinar; naturalmente habrá explicaciones más concretas desde el campo de la psicología que puedan avanzar alguna razón comprensible para que exista interés en visitar un lugar como Auschwitz por parte de individuos sin relación directa con ese lugar, más allá de la obvia mercantilización de las experiencias del pasado, entendidas éstas como placenteras. Se propone en este breve texto una reflexión teórica sobre esta temática enfocada en los procesos de memoria a través de las prácticas indisociables del olvido y el recuerdo.

En primer lugar, se debe recordar que, mediante el conocido recorrido diacrónico de la institucionalización de la práctica de la conservación y de la musealización, en esas mismas sociedades postindustriales, en las que nos situamos, el legado precedente llamado patrimonio ha sido tradicionalmente creado a través de discursos interpretativos mediante determinados criterios que tienden a una idea de exaltación de valores que se presuponen no traumáticos o negativos. Partiendo del concepto formulado por Laurajane Smith, el authorised heritage discourse (2006), que caracteriza esa misma práctica, éste presenta así una reciprocidad entre los discursos oficiales sobre un periodo temporal y su aceptación por un público generalizado, y que ha llevado a fenómenos de fruición pública. En este sentido, ¿por qué hemos llegado a la mercantilización de lugares con una historia ligada a acontecimientos traumáticos? ¿Para quién y por qué se conservan, clasifican y musealizan?

Debemos tener en cuenta que patrimonio, según defendemos, es un proceso de creación de identidade(s), a través de mecanismos de memoria, donde se apropian y reapropian elementos de nuestro entorno precedente, asignándoles significados según las exigencias de cada generación o cada tiempo presente (Harrison 2013; Smith 2006; Samuel 1994). Todos los lugares antrópicos han sido siempre escenarios de negociación de diferentes valores desde diversos grupos identitarios, que se materializan y/o se expresan mediante acciones intencionales como el abandono, la destrucción o la conservación. Tal como comenta John Pendlebury: "the nature of heritage is that it is socially constructed; value is never an intrinsic quality but is externally imposed according to culturally and historically specific frameworks [...]. Thus, value becomes an arena for plural interpretations and meaning. What need discussion therefore are conservation values: the reasons why, and what, we seek to conserve [...]. Finally, we need to think about who decides what happens - whose heritage is it? $(2009,214)$.

La memoria es así inherente a todo el proceso patrimonial, por lo cual todos los lugares antrópicos son lugares de memoria, y se debería por tanto repensar el concepto de museos de memoria.

Con respecto a los acontecimientos llamados traumáticos, teniendo en cuenta que la noción de trauma es variable desde varias perspectivas (desde el ámbito psicológico al cultural, así como su escala, desde la indi- 
a debate Interpretación y gestión del patrimonio en los espacios del turismo oscuro

| coordinan Óscar Navajas Corral y Maribel Rodríguez Achútegui

vidual, del grupo identitario, hacia valores identitarios compartidos a una escala nacional o global), debemos primero pensar que determinados acontecimientos de este género comprenden una pluralidad de valores, de vencedores y vencidos, por lo cual un mismo acontecimiento es tratado de manera diferente, y muchas veces de forma antagónica, entre diferentes grupos y sus respectivas generaciones.

En segundo lugar, naturalmente nos encontramos con diferentes modos o prácticas con las que las sociedades, o grupos identitarios, se han relacionado con estos acontecimientos: ¿es necesario el olvido, mediante la eliminación física y mental de las huellas de un evento traumático? ¿O bien se hace necesario un espacio-memorial para permitir que ese acontecimiento pueda seguir recordándose generación tras generación? Siendo el patrimonio un proceso, los valores a conservar pueden incluso perdurar sin una expresión física, por la cual la inexistencia matérica de elementos no significa que no exista patrimonio y éste no se conserve o perdure. Esto plantea quizás nuevas formas de mirar hacia el concepto de museología. Desde un ejemplo a priori no tan obvio, una nave abandonada de un antiguo espacio productivo del cual existen memorias traumáticas por parte de los trabajadores, la no intervención, o no musealización (en el sentido de las prácticas tradicionales) puede significar igualmente un espacio-memorial, mediante una conexión afectiva con el lugar, en su dimensión etérea, en el cual se procesan igualmente acciones de rememoración.

Por tanto, en los casos en los que se plantean acciones de conservación por la vía tradicional, o la existencia de un espacio-memorial, ¿a quién afecta exactamente? ¿Quiénes son los actores legítimos y cómo pueden elegir el destino de esos lugares ligados a un determinado evento traumático? Desde la esfera experta, ¿qué acciones estamos promoviendo para permitir la mercantilización de esos lugares, con la obsesión contemporánea conservativa y consecuentemente museológica? En los casos de un grupo identitario o los diferentes actores directamente ligados a una situación traumática, ¿se plantea la posibilidad de la destrucción de elementos físicos como acción integrante y de derecho propio de los procesos de memoria? ¿Es, en este sentido, ético explorar, bajo cualquier forma, un trauma que nos es teóricamente ajeno?

Ciertamente, y como es objetivo en la temática de la presente publicación, es necesario volver a repensar el proceso patrimonial fuera de la esfera institucional, y específicamente sobre el propósito primero de la conservación de los lugares del trauma. Su extraña musealización con el fin estricto de su promoción como experiencia cultural, para un público generalizado, genera sin duda problemáticas muy pertinentes. Es, además, un síntoma contemporáneo de la obsesión en conservar todo y cualquier acontecimiento del pasado, y de la fugacidad de nuestro presente (Hartog 2013), donde las memorias están siendo constantemente reemplazadas por otras; paradógicamente, el concepto de memoria no ha sido nunca tan estudiado y empleado (Miztal 2003 y Connerton 2009).

\section{BIBLIOGRAFÍA}

- Connerton, P. (2009) How modernity forgets. Cambridge: Cambridge University Press

- Harrison, R. (2013) Heritage: Critical Approaches. London: Routledge

- Hartog, F. (2013) Regimes de Historicidade. Presentismo e experiências do tempo. São Paulo: Autêntica

- Mistzal, B. (2003) Theories of social remembering. Philadelphia: Open University Press

- Pendlebury, J. (2009) Conservation in the Age of Consensus. London: Routledge

- Samuel, R. (1994) Theatres of Memory: Past and Present in Contemporary Culture. London: Verso

- Smith, L. (2006) Uses of Heritage. London: Routledge 